\title{
越婢加术湯が奏効した乾性咳嗽を伴う 漿液性膝関節炎の一例
}

$\begin{array}{llllll}\text { 星野 } & \text { 綾美 } \mathrm{a} & \text { 巽 } & \text { 武司 } \mathrm{b} & \text { 佐藤 } & \text { 浩子 } \mathrm{b} \\ \text { 奥 } & \text { 裕子 } \mathrm{a} & \text { 伊藤 } & \text { 克彦 } \mathrm{c} & \text { 田村 } & \text { 遵一 } \mathrm{a} \\ & & \text { 小暮 } & \text { 敏明 } \mathrm{b} & & \end{array}$

a 群馬大学医学部附属病院総合診療部, 群馬, 干371-8511 前橋市昭和町3-39-15

b 群馬大学医学部統合和漢診療学講座, 群馬, 干371-8511 前橋市昭和町3-39-22

c 山王タウンクリニック, 群馬, 干379-2123 前橋市山王町1-23-32

\section{A Case of Serous Gonarthritis with Nonproductive Cough Successfully Treated with Eppikajutsuto}

\author{
Ayami HOSHINO $^{\mathrm{a}}$ Takeshi TATSUMI $^{\mathrm{b}}$ Hiroko SATO $^{\mathrm{b}}$ \\ Yuko OKU $^{\mathrm{a}} \quad$ Katsuhiko ITO $^{\mathrm{c}}$ Jun'ichi TAMURA $^{\mathrm{a}}$ \\ Toshiaki KOGURE ${ }^{\mathrm{b}}$
}

a Department of General Medicine, Gunma University Hospital, 3-39-15 Syowa-machi, Maebashi-shi, Gunma 371-8511, Japan

b Department of Integrated Japanese Oriental Medicine, Gunma University School of Medicine, 3-39-22 Syowa-machi, Maebashi-shi, Gunma 371-8511, Japan

c Sanno Town Clinic, 1-23-32 Sanno-cho, Maebashi-shi, Gunma 379-2123, Japan

\begin{abstract}
We report a case of serous gonarthritis with nonproductive cough successfully treated with Eppikajutsuto. A 37-year-old Japanese man developed a right genicular arthrocele with nonproductive cough, in October X. Over $100 \mathrm{ml}$ of serous synovial fluid was drained via an arthrocentesis puncture procedure. Although he was treated with nonsteroidal anti-inflammatory agents by an orthopedist, under a diagnosis of serous gonarthritis, his symptoms did not improve. Laboratory findings suggested inflammatory conditions (serum CRP $3.4 \mathrm{mg} / \mathrm{dl}$, ESR $76 \mathrm{~mm} / \mathrm{h}$ ). At the time of his first visit in January $\mathrm{X}+1$, orthopedic examinations revealed that rheumatoid arthritis was unlikely, based on negative physical and laboratory findings. A contrast MRI knee joint scan did not demonstrate any tumor-like mass of synovium which would indicate pigmented villonodular synovitis. And orthopedists found it difficult to specify the cause of his serous gonarthritis. After a common cold in December X, cough stimulated by cold exposure was superimposed on serous gonarthritis.

We utilized Eppikajutsuto under the interpretation that both his genicular arthrocele and nonproductive cough were due to a "sui" disturbance. This Eppikajutsuto therapy reduced his genicular arthrocele and nonproductive cough in 1 month. His symptoms and inflammatory reactions were completely improved in 3 months, regardless of gradual withdrawal of his medication.
\end{abstract}

Key words : genicular arthrocele, nonproductive cough, Eppikajutsuto

\section{要旨}

今回，われわれは漿液性膝関節炎と乾性咳嗽に対し越婢加术湯が奏効した一例を経験したので報告する。症例は 37歳，男性。特記すべき既往歴なし。主訴は右膝関節腫張と乾性咳嗽。X年10月頃から特に誘引なく右膝の疼痛と 腫張が出現し，同年10月当院整形外科を受診。関節穿刺にて多量の漿液性の関節液が排液された。血清 CRP3.4 $\mathrm{mg} / \mathrm{dl}$ ，赤沈76mm/hの炎症所見を認めたが，身体所見，検査所見から関節リウマチは否定的で，膝関節造影 MRI 検査上, 色素性絨毛結節性滑膜炎を示唆する所見も認められす確定診断は困難とされた。NSAIDs 内服加療にも関 わらす膝関節腫張が遷延したことに加えて，同年12月末の感冒罹患を契機に，寒冷刺激で出現する乾性咳嗽を自覚 するようになったため, X+1 年 1 月当院総合診療部を受診した。診察所見や胸部レントゲン上明らかな異常を認 めず, 感冒後の気道過敏が考えられた。膝関節腫張と咳嗽に対し, 和漢診療を希望されたため, 同日から越婢加术 湯7.5g/日を投与した。内服 1 力月後には膝関節腫張は消失，咳嗽はほとんど自覚しない程度に改善し，CRP陰性 
となり，内服 3 力月で投薬中止となった。西洋医学的には原因不明の漿液性関節炎であったが，和漢診療学的には 陽実証の水滞と考えられ，越婢加术湯証が奏効した。

キーワード：漿液性膝関節炎，乾性咳嗽，越婢加术湯

\section{緒言}

関節炎の原因としては，関節リウマチや変形性膝 関節炎，痛風，外傷，感染など種々が考えられるが, 関連する疾患の種類や経過が多様であるため, 精査 を行っても原因が特定できない症例が時に経験され る。今回，我々は，西洋医学的には原因が特定でき ない漿液性関節炎に対し，合併症も考慮した和漢診 療学的所見から越婢加术湯証を得, 同処方が著効し た一例を経験したので文献的考察を加え報告する。

\section{症例}

症 例：37歳, 男性。

家族歴：特記すべきことなし。

既往歴：左側頸囊包（左頸部の腫瘤を20歳台から 自覚し, 耳鼻科での精査にて側頸囊胞の診断を受け 経過観察されている。感冒罹患時や疲労時などには やや腫大する傾向を自覚している)。

主 訴：右膝関節腫張と乾性咳嗽。

現病歴：X年10月頃から特に外傷などの誘引なく 右膝関節の疼痛と腫張が出現したため, 同年 10 月 29 日，当院整形外科を受診。関節穿刺にて $100 \mathrm{ml}$ 以上 の漿液性の関節液が排液された。血液検査上炎症反 応を指摘され, 膝関節レントゲン, 膝関節造影 MRI 検查では, 多量の関節液貯留と, 滑膜炎の所見を指 摘されたが，身体所見，検査所見から関節リウマチ は否定的で, 膝関節造影 MRI 検査上, 色素性絨毛 結節性滑膜炎を示唆する所見も認められず，確定診 断は困難とされた。関節痛に対しロキソプロフェン 内服 $60 \mathrm{mg} /$ 日による対症療法が行われた。以後, 症 状，炎症所見ともに遷延していた。同年12月末から は右膝関節腫張に加え, 感冒を契機として乾性咳嗽 が出現したため, 精查加療目的で X+1 年 1 月当院 総合診療部を受診した。

受診時身体所見：身長 $190.0 \mathrm{~cm}$, 体重 $84.0 \mathrm{~kg}$, 体温 $37.0^{\circ} \mathrm{C}$, 血圧 $126 / 76 \mathrm{mmHg}$, 脈拍 68 回/分。 頭頸部では, 眼球・眼瞼結膜に貧血・黄疸なく, 眼 の乾燥症状なし。口腔・咽頭には異常所見なく, 甲 状腺腫なし。左頸部に弾性軟, 径 $1 \mathrm{~cm}$ ほどの扁平 な腫瘤を触知した。胸部・腹部に明らかな異常所見
を認められなかった。右膝関節に軽度の熱感と自発 痛を伴う関節腫脹を認める。神経学的所見に異常は なかった。

受診時検査所見（表 1 ) : 白血球および血小板の 増加を認めた。尿所見は正常であった。血沈 $78 \mathrm{~mm} / \mathrm{h}$, CRP $3.4 \mathrm{mg} / \mathrm{dl}$ の炎症反応が認められたが，リウマチ 因子除性，抗核抗体陰性，MMP-3 に上昇を認めず, 関節リウマチを示唆する所見は認められなかった。 胸部レントゲン検査では，異常所見が認められず， 乾性咳嗽については, 身体所見と併せて感冒後の気 道過敏と考えられた。関節穿刺の結果, 漿液性の関 節液が $100 \mathrm{ml}$ 以上排液された。関節液の塗沫検鏡検 査,一般細菌培養検査では細菌陰性であった。本症 例の臨床像から, 滑膜の腫瘤様の増殖を特徵とする 色素性絨毛結節性滑膜炎が疑われ, 右膝関節造影 MRI 検査が行われ, 多量の関節液貯留と滑膜のび 慢性肥厚を指摘された（図 1 -A，B)。

和漢診療学的所見 : 自覚症状として口渇, 乾性咳, 自汗，右膝関節痛と痛みによる屈曲困難を訴えてい た。食欲・二便に異常はなかった。

他覚的には, 身長 $190 \mathrm{~cm}$ と大柄でがっしりした体 格。左頸部の側頸囊胞は径 $1 \mathrm{~cm} の$ 扁平な腫瘤とし て触知された。右膝関節に腫脹と熱感を触知した。 局所に発赤は認めなかった。脈は浮沈間・実。舌は 紅でやや乾燥した淡白苔がみられた。腹候では, 腹 力はやや実で，軽度の腹直筋緊張を認めた。

臨床経過：(図 2 ) 右膝の関節水腫は $\mathrm{X}$ 年 8 月 の発症から 5 カ月以上持続していた。この間, 末梢 血白血球数は $10,000 / \mu \mathrm{l}$ 前後, $\mathrm{CRP}$ は $3.7 \mathrm{mg} / \mathrm{dl}$ と, 炎症所見が陽性であった。また， $X$ 年の 12 月，感冒 に罹患した後, 乾性咳嗽が出現した。特に朝方や室 温の変化などに対して咳嗽が誘発され，咳き込みは じめると数分止まらない状況であった。 X+ 1 年 1 月 6 日の初診日より, 越婢加术湯エキス（ツム ラ， $7.5 \mathrm{~g} /$ 日）を投与したところ, 内服 2 週後には 膝関節腫張が半減し, 内服 1 力月後には腫張が消失, 咳嗽は朝方数回軽い咳嗽が出るのみに改善, CRP 陰性となった。内服 2 カ月目ころより, 左側頸囊胞 
表 1 受診時検査所見

\begin{tabular}{|c|c|c|c|c|c|c|}
\hline [血算］ & & & 化学］ & & & [免疫］ \\
\hline RBC & \multicolumn{2}{|c|}{$416 \times 10^{4} / \mu l$} & TP 8.0 & $g / d l$ & & $\mathrm{mg} / \mathrm{dl}$ \\
\hline $\mathrm{Hb}$ & 12.4 & $\mathrm{~g} / \mathrm{dl}$ & T. Bil. & 0.4 & $\mathrm{mg} / \mathrm{dl}$ & $\mathrm{RF}<10$ \\
\hline $\mathrm{Ht}$ & 38.7 & $\%$ & AST & 14 & IU/I & 抗核抗体 (-) \\
\hline WBC & 10000 & $|\mu|$ & ALT & 44 & $\mathrm{IU} / \mathrm{I}$ & \multirow{2}{*}{$\begin{array}{llr}\text { MMP-3 } & 83.7 & \mathrm{ng} / \mathrm{ml} \\
& (36.9-121.0)\end{array}$} \\
\hline \multirow{2}{*}{ Platelet } & \multirow{2}{*}{\multicolumn{2}{|c|}{$68.4 \times 10^{4} / \mu \mathrm{l}$}} & LDH & 151 & $\mathrm{IU} / 1$ & \\
\hline & & & UA & 4.8 & $\mathrm{mg} / \mathrm{dl}$ & 抗DNA抗体 \\
\hline [血沈］ & \multirow[t]{2}{*}{78} & $\mathrm{~mm} / \mathrm{h}$ & BUN & 10 & $\mathrm{mg} / \mathrm{dl}$ & 抗RNP抗体 \\
\hline \multicolumn{2}{|l|}{ [随時尿］ } & & $\mathrm{Cr}$ & 0.7 & $\mathrm{mg} / \mathrm{dl}$ & 抗Sm抗体 \\
\hline $\mathrm{pH}$ & & 7.5 & $\mathrm{Na}$ & 140 & $\mathrm{mEq} / \mathrm{l}$ & 抗SS-A抗体 \\
\hline \multirow{2}{*}{ 蛋白 } & & $(-)$ & K & 4.4 & $\mathrm{mEq} / \mathrm{l}$ & 抗SS-B抗体 \\
\hline & 糖 & $(-)$ & $\mathrm{Cl}$ & 105 & $\mathrm{mEq} / \mathrm{l}$ & 抗scl-70抗体 \\
\hline 潜血 & & $(-)$ & & & & 抗年㐰ゲロブリ抗体＜100倍 \\
\hline \multirow{2}{*}{ 白血球 } & & $(-)$ & & & & 抗マ侈ロゾ-ム抗体＜100倍 \\
\hline & & & & & & 抗ミコンドリア抗体（-) \\
\hline
\end{tabular}
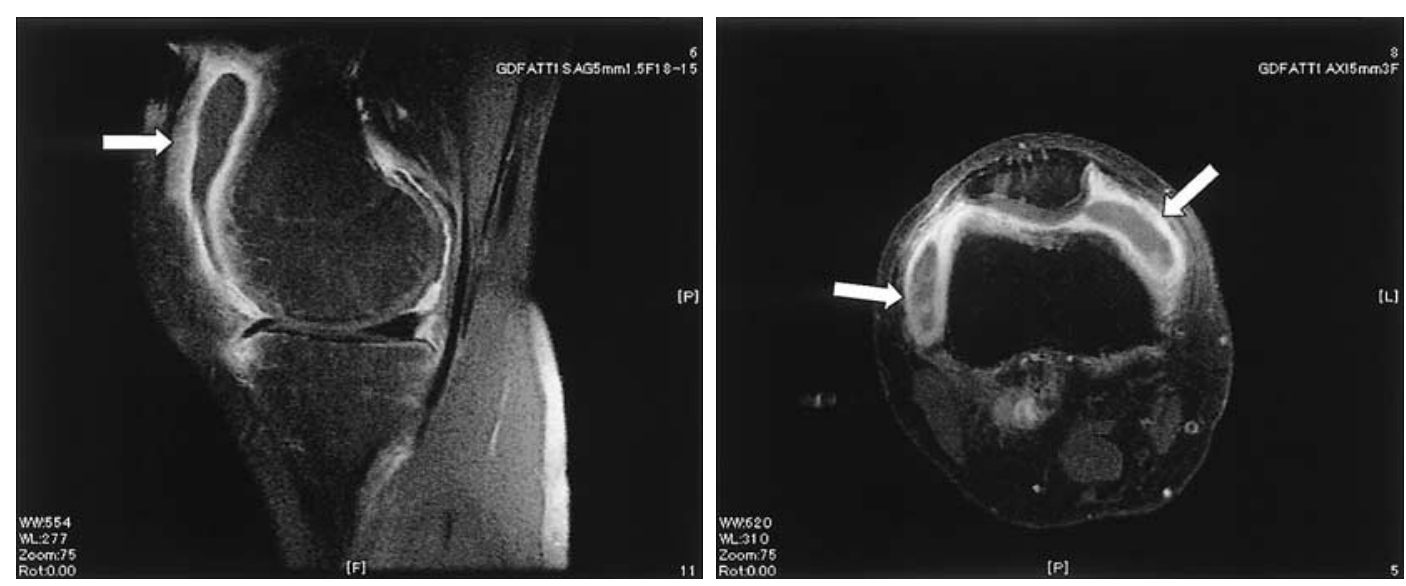

A

B

图 1

A, B : 右膝関節造影 MRI.T 1, 脂肪抑制条件。比較的大量の関節液貯留を認め, 滑膜のび慢 性の肥厚が明らかだが (矢印), 腫瘤様の部分は認められず，色素性緁毛結節性滑膜炎を示唆す る所見はない。内外半月板，勒帯には異常を認めず，骨は正常の所見であった。

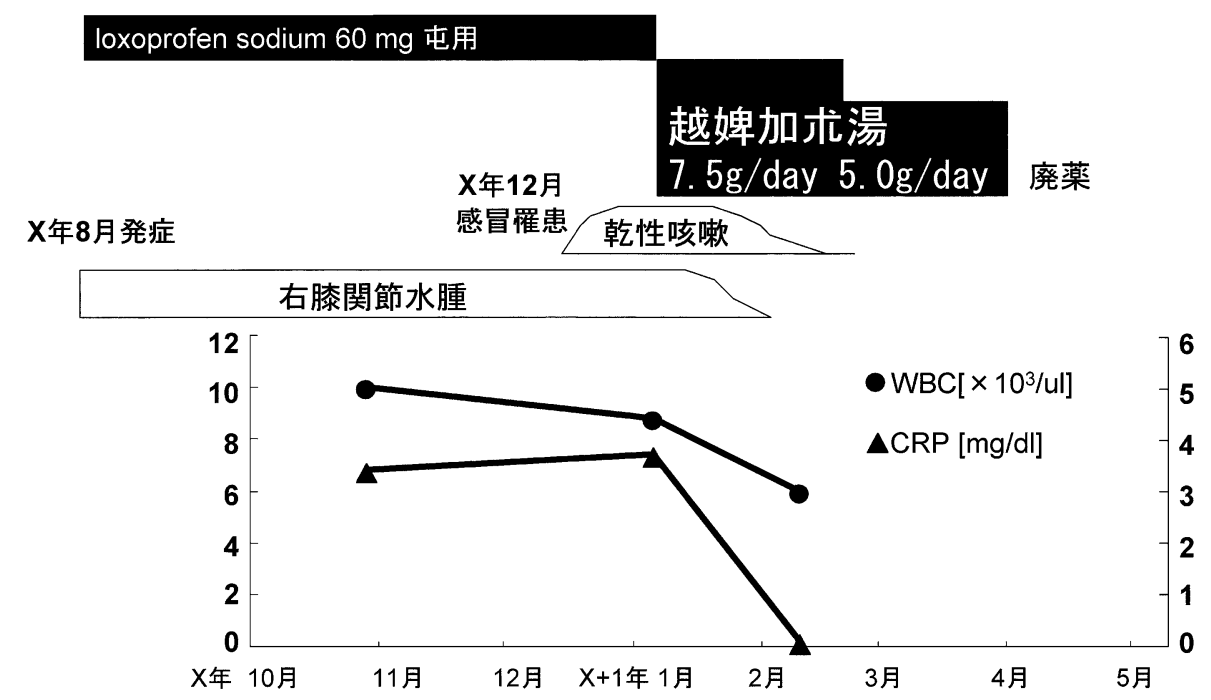

図 2 臨床経過 
表 2 越婢加术湯の主な治験報告例

\begin{tabular}{|c|c|c|c|}
\hline 報告者 & 雑誌 & 症例 & 報告年 \\
\hline 佐藤 弘 ほか & 漢方研究 & アレルギ一性鼻炎と貨幣状湿疹 & 2005 \\
\hline 中村謙介 & 漢方の臨床 & 陥入爪術後、膝関節痛 & 2004 \\
\hline 重軒正宏 ほか & 漢方医学 & 急性痛風関節炎 & 2004 \\
\hline 瀧本 眞 & ペインクリニック & 帯状疮疹後神経痛の予防 & 2004 \\
\hline 中村謙介 & 漢方の臨床 & 色素性緁毛結節性滑膜炎 & 2004 \\
\hline 夏秋 優 & Derma & 湿潤したアトピ一性皮膚炎 & 2001 \\
\hline 井上裕章 & 耳鼻と臨床 & 成人滲出性中耳炎に小青竜湯と併用 & 2001 \\
\hline 松田史彦 ほか & 日本東洋医学雑誌 & 回帰性リウマチ & 2001 \\
\hline 杉山誠一 & 日本東洋医学雑誌 & 膝関節水腫-熱感·圧痛を伴う変形性膝関節症 & 1997 \\
\hline 阿部勝利 ほか & 日本東洋医学雑誌 & 小児および若年成人の気管支喘息 & 1991 \\
\hline 大内広子 ほか & 現代東洋医学 & 関節リウマチに真武湯加越婢加术湯 & 1988 \\
\hline 三田哲郎 ほか & 漢方診療 & 汎発性皮膚掻痒症 & 1987 \\
\hline
\end{tabular}

表 3 関節水腫を伴う膝関節炎に対する主な治験報告例

\begin{tabular}{|c|c|c|c|c|}
\hline 有効方剂 & 主な改善所見 & 報告者 & 雑誌 & 報告年 \\
\hline 防已黄耆湯加味 & OAの関節水腫 & 首藤孝夫 ほか & 漢方医学 & 2005 \\
\hline 竜胆瀉肝湯合六味丸 & OAの関節痛 & 壇上健作 & 漢方研究 & 2004 \\
\hline 越婢加半夏湯 & 膝関節痛と咳 & 仲原靖夫 & 漢方の臨床 & 2004 \\
\hline 柴苓湯 & OAの疼痛 & 松村重之 & 新薬と臨床 & 2002 \\
\hline 防已黄耆湯 & OAの疼痛と下腿浮腫 & 恩田芳和 & 痛みと漢方 & 2001 \\
\hline 大黄甘遂湯 & $\begin{array}{l}\text { バセドウ病を伴うOAの腺関 } \\
\text { 節痛と下腿浮腫 }\end{array}$ & 田原英一 ほか & 日本東洋医学雑誌 & 1998 \\
\hline 越婢加术湯 & OAの関節水腫、疼痛 & 杉山誠一 & 日本東洋医学雑誌 & 1997 \\
\hline 八味地黄丸 & OAの疼痛、熱感 & 前田繁男 ほか & 日本東洋医学雑誌 & 1994 \\
\hline 越婢加术湯 & 膝関節水腫と疼痛、咳嗽 & & 自験例 & 2005 \\
\hline
\end{tabular}

が触知しにくいほどに縮小した。本人が内服を忘れ るようになり, 自覚症状が消失したため, 内服 3 カ 月で投薬中止とし, X+1 年 5 月時点で症状再発を 認めなかったため, 終診となった。

\section{考察}

越婢加术湯の出典は金貴要略「中風歴節病脈証併 治第五」に，「千金方の越婢加术湯は，肉極にて熱 すれば則ち身体の津脱し, 腠理開き, 汗大いに泄れ, 属風気, 下焦, 脚弱きを治す。とあり, 下肢の浮 腫や変形性膝関節症などに用いられてきた。

越婢加尤湯の主な治験報告例（表 2 ）では, 変形 性膝関節症や急性痛風関節炎, 関節リウマチなど, 炎症と関節水腫を認めた症例の報告が多いほか，ア
レルギー性鼻炎や湿潤したアトピー性皮膚炎，中耳 炎など，広く「水」の異常を伴う病態に応用されて

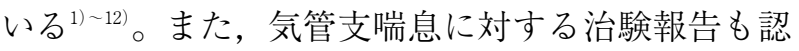
められた。

関節水腫を伴う膝関節炎に対する主な治験報告例 を示す (表 3 )。防已黄者湯や柴苓湯, 越婢加术湯 や八味丸など，利水剂が多く用いられていた ${ }^{13) ~ 20) 。 ~}$ 同じ越婢湯を含む越婢加半夏湯に関して, 本症例と 類似の膝関節炎と咳嗽に対する治験報告が認められ た ${ }^{15)}$ 。本症例は身長 $190.0 \mathrm{~cm}$, 体重 $84.0 \mathrm{~kg}$ と非常に 大柄でがっしりした体格であり, 熱感・腫脹を伴う 強い膝関節炎を認めたことから，陽証で実証の水滞 を伴う状態と考えられた。関節炎から越婢加术湯や 
麻杏薏甘湯，薏茨仁湯を考慮したが，口渴の存在や 咳き込み始めると数分間止まらない乾性咳嗽の存在 から越婢加尤湯を投与し，奏効した。漿液性膝関節 炎の治療に際し, 越婢加术湯の適応を勘案する際, 乾性咳嗽の存在がひとつの指標となる可能性が示唆 された。

\section{まとめ}

漿液性膝関節炎と乾性咳嗽に対し，越婢加术湯が 奏効した一例を報告した。本症例は滑膜のび慢性肥 厚，高度な関節水腫を伴う膝関節炎と，乾性咳嗽を 合併しており，熱の存在と水の異常が考えられた。 西洋医学的に原因が特定されない本症例に対しても, 証に基づいて使用した和漢薬が奏効した。

附記 : 本稿の要旨は平成 17 年度日本東洋医学会群馬 県部会（前橋・2005年）に扔いて報告した。

\section{文献}

1）佐藤弘：アレルギ一性鼻炎（季節型）と貨幣状湿 疹に対する方剂と針法，漢方研究，398，10-11 (2005)

2 ）中村謙介：陥入爪術後 - 外傷性膝関節炎, 漢方の 臨床，51，1692-1693（2004）

3 ）重軒正宏, 京極新治, 竹内辰五郎：急性痛風関節 炎様の関節痛に対する越婢加术湯の使用経験，漢 方医学，28，172-175（2004）

4 ）瀧本眞：越婢加术湯の帯状疮疹後神経痛に対する 予防効果の検討，ペインクリニック，25，10731079 (2004)

5 ）中村謙介：漢方牛歩録 急性反覆性の多発性関節 炎・更年期のほてり，漢方の臨床， 51，242-245 (2004)

6 ) 夏秋優：最新アトピー性皮膚炎診療マニュアル 漢方薬の選び方，Derma， 54，60-65（2001）

7 ) 井上裕章：成人渗出性中耳炎急性例に対する小青 竜湯・越婢加术湯併用投与の即効性，耳鼻と臨床,
47, 361-366 (2001)

8 ）松田史彦, 新井信, 佐藤弘, 代田文彦, 関直樹 : 漢方治療が有効であった回帰性リウマチの 3 症例, 回帰性リウマチの漢方治療に関する一考察, 日本 東洋医学雑誌，51，741-749（2001）

9 ）杉山誠一：変形性膝関節症に対する越婢加术湯の 効果，日本東洋医学雑誌，48，319-325（1997）

10）阿部勝利，高木清文：小児気管支喘息に対する煎 剤の越婢加半夏湯ならびにエキス夙の越婢加术湯 合半夏厚朴湯の有効性, 日本東洋医学雑誌,

42，271-281 (1991)

11）大内広子, 保母光彦: 難病 - 難症の漢方治療 慢 性関節リウマチの真武湯加越婢加术湯使用例， ス テロイド使用例と金製剂＋漢方例との比較につい て，現代東洋医学，9，143-145（1988）

12）三田哲郎，安江厚子：沉発性皮膚掻痒症に対する 越婢加术湯の使用経験，漢方診療，6，41-44 (1987)

13）首藤孝夫：変形性膝関節症の漢方治療 防已黄者 湯加味，漢方医学，29，65-70（2005）

14）壇上健作 : 変形性膝関節症の治療その 2 , 漢方研 究，394，400-402（2004）

15）仲原靖夫：関節痛と咳を訴える症例 水毒の病理 の考察，漢方の臨床， 51，918-921（2004）

16）松村重之：柴苓湯の変形性膝関節症に対する臨床 的有用性の検討, 新薬と臨床, 51, 350-352 (2002)

17）恩田芳和：膝関節痛に対する防已黄者湯の使用効 果，痛みと漢方，11，59-61（2001）

18）田原英一，伊藤隆，林克美他：大黄甘遂湯が奏効 したバセドウ病を伴う変形性関節症の一例，日本 東洋医学雑誌，48，459-466（1998）

19）杉山誠一：変形性膝関節症に対する越婢加术湯の 効果，日本東洋医学雑誌，48，319-325（1997）

20）前田繁男，無敵剛介：変形性膝関節症に対する八 味地黄丸を中心とした漢方治療の有用性，日本東 洋医学雑誌，44，569-574（1994） 